\title{
Female hormones prevent sepsis-induced cardiac dysfunction: an experimental randomized study
}

\author{
Alexandre Xerri ( $\nabla$ xerri.alex@gmail.com ) \\ Marseille Public University Hospital System \\ Frédéric Gallardo
}

Aix-Marseille University

Frank Kober

French National Centre for Scientific Research

\section{Calypso Mathieu}

Marseille Public University Hospital System

Natacha Fourny

Aix-Marseille University

Thi Thom Tran

Inserm

Jean-Louis Mege

Aix-Marseille University

Mervyn Singer

University College London

Nathalie Lalevée

Inserm

\section{Monique Bernard}

French National Centre for Scientific Research

Marc Leone

Aix-Marseille University

\section{Research Article}

Keywords: Septic shock, septic cardiopathy, ovariectomy, beta-blocker, landiolol

Posted Date: June 9th, 2021

DOl: https://doi.org/10.21203/rs.3.rs-598575/v1

License: (9) This work is licensed under a Creative Commons Attribution 4.0 International License.

Read Full License 


\section{Abstract}

Introduction: Although epidemiologic research has demonstrated significant differences in incidence and outcomes of sepsis according to gender, their underlying biological mechanisms are poorly understood. Here, we studied the influence of hormonal status by comparing in vivo cardiac performances measured by MRI in non-ovariectomized and ovariectomized septic female rats.

Methods: Control and ovariectomized rats were randomly allocated to the following groups: sham, sepsis and sepsis plus landiolol. Sepsis was induced by caecum ligation and punction (CLP). Cardiac MRI was carried out 18 hours after induction of sepsis to assess in vivo cardiac function. Capillary permeability was evaluated by Evans Blue administration and measurement of its tissue extravasation. Variation in myocardial gene expression was also assessed by qPCR in the left ventricular tissue.

Results: Sepsis reduced indexed stroke volume, cardiac index and indexed end-diastolic volume compared to sham group in ovariectomized females whereas it had no effect in control females. Landiolol increased the indexed stroke volume by reversing the indexed end-diastolic volume reduction after sepsis in ovariectomized females, while it decreased indexed stroke volume and cardiac index in control. Major differences in the left ventricular expression of genes coding for calcium signalling and contractile proteins were observed in ovariectomized females compared to control after sepsis, partially restored by landiolol. Moreover, in control females, increase of apoptotic genes by sepsis was maintained after landiolol infusion.

Conclusions: Sepsis decreased in vivo cardiac performances in ovariectomized females but not in control females, presumably associated with apoptosis and calcium protein-related contractility defects. Administration of landiolol prevents this cardiac dysfunction in ovariectomized females, while it has deleterious effects in control females.

\section{Introduction}

Epidemiological studies have shown that both incidence and outcome of sepsis differ according to gender, with a protective effect of female gender $(1-3,5,6)$. Interestingly, this difference of outcome was not found in old patients, which suggests an influence of hormonal status (2).

This influence is exerted in particular at the cardiovascular level. In a murine model of sepsis induced by cecal ligation and punction (CLP), Chen et al. have previously described a gender dimorphism of the septic cardiac dysfunction (7). Our team showed in vivo that female gender was protective for cardiac dysfunction using a model of rat undergoing CLP (8).

Hence, there is an overall accumulation of clues suggesting a crucial role of the hormonal status in the control of sepsis-related cardiovascular dysfunction, as it is in other experimental models of cardiovascular dysfunction like trauma-hemorrhage and myocardial ischemia-reperfusion $(9,10)$. This prompted us to investigate the effect of ovariectomy on the cardiovascular response to sepsis. 
In our previous study, we evaluated the influence of gender on the response to a promising treatment in sepsis, the landiolol, a short-acting selective $\beta 1$-adrenergic blocker. Administration of landiolol improved the in vivo cardiac performance of septic male rats, whereas deleterious effects were found in female rats (8).

We thus compared in vivo cardiac performances measured by MRI in control and ovariectomized septic female rats, treated by landiolol. Capillary permeability was also evaluated by Evans Blue administration and measurement of its tissue extravasation. Finally, cardiac gene expression was investigated in the left ventricular tissue.

\section{Methods}

\section{Animals and surgical procedures}

Female Wistar rats (8-9-week-old, Charles River, Saint-Germain sur l'Arbresle, France) were housed for a 57-day acclimatization period in a temperature and light controlled room with free access to water and food. All animal procedures were conducted in accordance with the National Guidelines for Care and Use of Laboratory Animals in conformity with the 2010/63 EU directive and with the approval of the Institutional Animal Care Committee of Aix-Marseille University (APAFIS number 17814-

2019012215408140). Bilateral ovariectomy procedure is reported in the supplemental data. Anaesthetic and CLP procedures were performed as previously described (8).

\section{Experimental Protocol}

Figure 1 summarizes the experimental protocol. Ovariectomized (OVR) and control female rats were randomized to underwent a control laparotomy or the induction of sepsis by caecum ligation and punction (CLP). A delay of 3 to 4 weeks after the ovariectomy was respected. One hour after CLP, they were again randomized to receive landiolol (AOP Orphan, Vienna, Austria) diluted in n-saline and infused at $0.1 \mathrm{mg} / \mathrm{kg} / \mathrm{min}$ or $\mathrm{n}$-saline $(0.8 \mathrm{~mL} / \mathrm{kg} / \mathrm{hr})$. The infusion volume was similar in all groups. Six groups were assessed: sham $(n=7)$, sepsis $(n=8)$, sepsis plus landiolol $(n=7)$, OVR-sham $(n=7)$, OVR-sepsis ( $=6)$, and OVR-sepsis plus landiolol $(n=7)$. Eighteen hours after CLP, female rats were anesthetized using $1.8-2 \%$ isoflurane. The caudal ventral artery was cannulated (24-gauge catheter) for blood pressure recording (TruWave pressure; Edwards Lifesciences, Irvine, CA). Systolic blood pressure (SBP), diastolic blood pressure (DBP), mean blood pressure (MBP) and heart rate (HR) were recorded at H18. Body weight variations between $\mathrm{H} 0$ and $\mathrm{H} 18$ were measured. Cardiac MRI was performed 18 hours after CLP to assess the in vivo cardiac function (cine-MRI). Immediately after cardiac MRI, $2 \mathrm{~mL} / \mathrm{kg}$ of $4 \%$ Evans Blue (EB) solution were injected to female rats. After $30 \mathrm{~min}$, lungs were removed for subsequent measurement of EB tissue concentration, and hearts were frozen for subsequent quantification of gene expression.

\section{MRI Assessment of In Vivo Cardiac Function}


MRI was performed 18 hours after CLP, immediately after arterial cannulation. During MRI, inhalation anaesthesia was maintained with $1.5-2 \%$ isoflurane in $1.5 \mathrm{~L} /$ min oxygen continuously delivered through a face mask as previously described(8). Details are provided in the supplemental data.

End-diastolic volume (EDV), end-systolic volume (ESV), stroke volume (SV), left ventricle ejection fraction (LVEF), left ventricular mass (LVM), mean wall thicknesses in diastole and systole, and systolic wall thickening (WTn) were calculated from the volume measurements, as previously described (11). Cardiac output (CO) was calculated as CO = HR $\times$ SV. EDV (indexed EDV (EDVi)), ESV (indexed ESV (ESVi)), SV (indexed SV (SVi)), and Cl were indexed to weight. Image analyses were performed using a home-made program running in IDL environment.

\section{In vivo assessment of vascular permeability}

Immediately after cardiac MRI, $2 \mathrm{~mL} / \mathrm{kg}$ of $4 \%$ EB solution was injected to female rats, corresponding to a dose of $80 \mathrm{mg} / \mathrm{kg}$ of EB. This was calculated so that all injected EB is bound to albumin (12). Female rats were maintained 30 minutes under anaesthesia to insure a distribution of EB to the vascular system. At $30 \mathrm{~min}$, female rats were euthanized by $100 \mathrm{mg} / \mathrm{kg}$ of phenobarbital. Medial laparotomy was then performed, and the abdominal aorta was severed just below the renal arteries. Twenty millilitres of phosphate buffered saline at $4^{\circ} \mathrm{C}$ were injected in the jugular vein to wash the blood and remaining EB from the vascular system. After bilateral thoracotomy cranial pulmonary lobe were removed for analysis.

Removed tissues were incubated 48 hours at $55^{\circ} \mathrm{C}$ with $4 \mathrm{~mL} / \mathrm{g}$ of wet tissue of formamide, in order to extract the EB from the tissue. The EB/formamide mixtures were then centrifuged for 15 min at $4000 \mathrm{rpm}$. Supernatant was collected and absorbance at $610 \mathrm{~nm}$ was measured. Extravasated EB concentration per mg tissue was calculated.

\section{Plasma samples}

Blood samples were collected through the jugular vein before CLP and through arterial catheter after cardiac-MRI but before EB injection, centrifuged $\left(2,000 \mathrm{~g}, 12 \mathrm{~min}, 4^{\circ} \mathrm{C}\right)$, and the resulting plasma aliquoted and stored at $-80^{\circ} \mathrm{C}$ until biochemical analysis.

\section{RNA Extraction and Quantitative Reverse Transcriptase-Polymerase Chain Reaction}

Hearts, removed immediately after euthanasia, were dissected, frozen and stored at $-80^{\circ} \mathrm{C}$ until analyses. Total RNA was isolated from the left ventricles and qPCR experiments were performed as previously described (13).

\section{Statistical Analyses}

Data are expressed as means \pm SEM. After statistical evaluation, the number of rats required was 6 per group to show a $30 \%$ increase in SV by landiolol with a power of $80 \%$ and an alpha risk of $5 \%$. Significant differences between groups were determined using two-way analysis of variance followed by Sidak post hoc testing with GraphPad Prism software (GraphPad Prism 7.03, La Jolla, CA). A $p$ value of less than 0.05 was considered statistically significant. 


\section{Results}

\section{General effect of ovariectomy}

OVR females had an increased weight gain compared to control ( $p<0.001$ for sham groups; $p<0.05$ for sepsis groups and $p<0.01$ for sepsis plus landiolol groups) (Table 1). Body temperature and hemodynamic variables were similar in all groups.

After weight indexing, cardiac variables assessed by MRI were unchanged between OVR and control females (Fig. 2). There were no differences of left ventricular mass between OVR and control females of corresponding groups.

No significant differences were found in EB concentrations in lung tissue between OVR and control females of corresponding groups. There were no differences in lactate and procalcitonin plasma concentrations as well (Table 2).

\section{Effects of sepsis on cardiac function in OVR females}

Sepsis did not affect the weigh, respiratory rate and body temperature at H18. In control females, hemodynamic variables were similar after the sepsis procedure. In OVR females, sepsis decreased systolic blood pressure $(p<0.05)$, as compared with sham (Table 1$)$.

Sepsis did not affect the cardiac performances in control females; no differences of cardiac index (Cl) indexed stroke volume (SVi), and indexed end diastolic volume (EDVi) were reported, as compared with sham. In contrast, in OVR females, sepsis decreased the $\mathrm{Cl}$ by $52 \%(p<0.0001)$ and SVi by $53 \%(p<$ $0.0001)$, reflecting the global performance of the heart. 
Table 1

Physiological and hemodynamic parameters 18 hrs after CLP

\begin{tabular}{|c|c|c|c|c|c|c|}
\hline \multirow{2}{*}{$\begin{array}{l}\text { Measured } \\
\text { parameters }\end{array}$} & \multicolumn{3}{|l|}{ Control } & \multicolumn{3}{|l|}{ OVR } \\
\hline & $\begin{array}{l}\text { sham } \\
(n=6)\end{array}$ & $\begin{array}{l}\text { sepsis } \\
(n=5)\end{array}$ & $\begin{array}{l}\text { sepsis + Landiolol } \\
(n=5)\end{array}$ & $\begin{array}{l}\text { sham } \\
(n=6)\end{array}$ & $\begin{array}{l}\text { sepsis } \\
(n=6)\end{array}$ & $\begin{array}{l}\text { sepsis + Landiolol } \\
(n=6)\end{array}$ \\
\hline Age (weeks) & $\begin{array}{l}11.2 \pm \\
0.2\end{array}$ & $\begin{array}{l}11.6 \pm \\
0.4\end{array}$ & $11.7 \pm 0.5$ & $\begin{array}{l}12.3 \pm \\
0.6\end{array}$ & $\begin{array}{l}12.2 \pm \\
0.4\end{array}$ & $12.2 \pm 0.5$ \\
\hline Initial weight (g) & $\begin{array}{l}183 \pm \\
7\end{array}$ & $\begin{array}{l}196 \pm \\
9\end{array}$ & $203 \pm 8$ & $\begin{array}{l}191 \pm \\
7\end{array}$ & $\begin{array}{l}185 \pm \\
11\end{array}$ & $198 \pm 10$ \\
\hline $\begin{array}{l}\Delta \text { weight post- } \\
\text { OVR (g) }\end{array}$ & $38 \pm 5$ & $42 \pm 5$ & $48 \pm 13$ & $\begin{array}{l}96 \pm \\
7^{++t}\end{array}$ & $\begin{array}{l}81 \pm \\
5^{+}\end{array}$ & $99 \pm 11^{\dagger \dagger}$ \\
\hline $\begin{array}{l}\Delta \text { weight post- } \\
\text { CLP (g) }\end{array}$ & $11 \pm 3$ & $16 \pm 2$ & $19 \pm 4$ & $19 \pm 3$ & $20 \pm 2$ & $10 \pm 2$ \\
\hline RR (cycles/min) & $50 \pm 1$ & $56 \pm 4$ & $53 \pm 4$ & $55 \pm 5$ & $56 \pm 5$ & $61 \pm 6$ \\
\hline $\begin{array}{l}\text { Temperature } \\
\left({ }^{\circ} \mathrm{C}\right)\end{array}$ & $\begin{array}{l}35.9 \pm \\
0.2\end{array}$ & $\begin{array}{l}35.6 \pm \\
0.2\end{array}$ & $34.5 \pm 0.6$ & $\begin{array}{l}35.8 \pm \\
0.2\end{array}$ & $\begin{array}{l}35.1 \pm \\
2\end{array}$ & $35.5 \pm 0.5$ \\
\hline SBP $(\mathrm{mmHg})$ & $\begin{array}{l}126 \pm \\
2\end{array}$ & $\begin{array}{l}113 \pm \\
1\end{array}$ & $92 \pm 7^{\star *}$ & $\begin{array}{l}126 \pm \\
5\end{array}$ & $94 \pm 5^{*}$ & $102 \pm 10$ \\
\hline $\mathrm{DBP}(\mathrm{mmHg})$ & $90 \pm 4$ & $77 \pm 8$ & $59 \pm 8$ & $84 \pm 4$ & $68 \pm 2$ & $69 \pm 8$ \\
\hline $\mathrm{MBP}(\mathrm{mmHg})$ & $\begin{array}{l}102 \pm \\
3\end{array}$ & $89 \pm 5$ & $70 \pm 7^{\star \star}$ & $98 \pm 4$ & $77 \pm 3$ & $80 \pm 9$ \\
\hline $\mathrm{HR}$ (bpm/min) & $\begin{array}{l}389 \pm \\
15\end{array}$ & $\begin{array}{l}397 \pm \\
11\end{array}$ & $358 \pm 14$ & $\begin{array}{l}382 \pm \\
10\end{array}$ & $\begin{array}{l}389 \pm \\
21\end{array}$ & $357 \pm 16$ \\
\hline \multicolumn{7}{|c|}{$\begin{array}{l}\text { Age: age at the time of CLP; } \Delta \text { weight post-OVR: weight difference between OVR and CLP procedures; } \\
\Delta \text { weight post-CLP: weight difference between CLP and } 18 \text { hours after; RR: Respiratory rate. SBP: } \\
\text { Systolic blood pressure; DBP: Diastolic blood pressure; MBP: Mean blood pressure; HR: Heart rate. } \\
\text { Data are expressed as means } \pm \text { SEM. }\end{array}$} \\
\hline \multicolumn{7}{|c|}{${ }^{\dagger} p<0.05 ;{ }^{\dagger \dagger} p<0.01 ;{ }^{+\dagger} p<0.001$ vs control of corresponding group. } \\
\hline
\end{tabular}

This alteration did not affect the cardiac systolic function, as there was no significant difference in left ventricular ejection fraction (LVEF), but the diastolic function: EDVi was decreased by $43 \%(p<0.0001)$, as compared with sham (Fig. 2). Of note, sepsis did not affect left ventricular mass in both control and OVR females. 
Table 2

Biological parameters $18 \mathrm{hrs}$ after CLP

\begin{tabular}{|c|c|c|c|c|c|c|}
\hline \multirow{2}{*}{$\begin{array}{l}\text { Biological } \\
\text { parameter }\end{array}$} & \multicolumn{3}{|c|}{ Control } & \multicolumn{3}{|l|}{ OVR } \\
\hline & $\begin{array}{l}\text { sham } \\
(n= \\
5)\end{array}$ & $\begin{array}{l}\text { sepsis } \\
(n=5)\end{array}$ & $\begin{array}{l}\text { sepsis + Landiolol } \\
(n=4)\end{array}$ & $\begin{array}{l}\text { sham } \\
(\mathrm{n}= \\
6)\end{array}$ & $\begin{array}{l}\text { sepsis } \\
(n=6)\end{array}$ & $\begin{array}{l}\text { sepsis + Landiolol } \\
(n=5)\end{array}$ \\
\hline $\begin{array}{l}\text { Evans Blue } \\
\text { (ng/mg tissue) }\end{array}$ & $\begin{array}{l}59 \pm \\
18\end{array}$ & $\begin{array}{l}92 \pm \\
10\end{array}$ & $108 \pm 31$ & $\begin{array}{l}37 \pm \\
11\end{array}$ & $\begin{array}{l}125 \pm \\
27\end{array}$ & $90 \pm 22$ \\
\hline $\begin{array}{l}\text { Lactate } \\
(\mathrm{ng} / \mu \mathrm{l})\end{array}$ & $\begin{array}{l}74 \pm \\
16\end{array}$ & $\begin{array}{l}145 \pm \\
29\end{array}$ & $111 \pm 35$ & $\begin{array}{l}79 \pm \\
18\end{array}$ & $\begin{array}{l}191 \pm \\
34\end{array}$ & $173 \pm 41$ \\
\hline $\begin{array}{l}\text { Procalcitonin } \\
(\mathrm{pg} / \mu \mathrm{l})\end{array}$ & $\begin{array}{l}14 \pm \\
5\end{array}$ & $20 \pm 5$ & $41 \pm 13$ & $\begin{array}{l}20 \pm \\
9\end{array}$ & $\begin{array}{l}48 \pm \\
16\end{array}$ & $39 \pm 11$ \\
\hline
\end{tabular}

Evans Blue: Evans Blue tissue concentration in pulmonary right cranial lobe; Lactate: Lactate plasma concentrations; Procalcitonin: Procalcitonin plasma concentration. Data are expressed as means \pm SEM.

In control females, sepsis did not increase EB tissue concentration, as compared with sham. Similarly, in OVR females, sepsis did not increase EB concentration in lung tissues, as compared with sham ( $p=$ 0.054). No significant differences were found in lactate and procalcitonin plasma concentrations after sepsis between control and OVR females (Table 2).

In order to identify transcriptional changes associated with ovariectomy in sepsis-induced cardiac dysfunction, we analysed by qPCR the expression in the left ventricle of genes encoding signalling proteins known for their role in cardiac and immune functions. In both control and OVR females, sepsis increased the myocardial expression of genes encoding protein associated to inflammation, interleukin-6 (IL-6), IL-10 and IL-18, to cell cycle and survival, Janus Kinase 2 (JAK2) and signal transducer and activator of transcription 3 (STAT3) (Table 3). Regarding pro-apoptotic genes, sepsis increased the cAMP responsive element modulator (CREM) in both control and OVR females, mitogen activated protein kinase 14 (MAPK14) in OVR females, and tumor necrosis factor- a (TNF-a) in control females (Table 3).

Moreover, the anti-apoptotic protein A-kinase anchoring protein 6 (AKAP6) was decreased after sepsis in control and OVR females.

However, in OVR females, sepsis also decreased gene expression of the adrenergic pathway, a- adrenergic receptor (a-AR) and phospholipase $\mathrm{C}$ beta 4 (PLCB4), and increased G protein-coupled receptor kinase 5 (GRK5) that inhibits the adrenergic pathway. Sepsis acted on genes involved in the regulation of intracellular calcium in an opposite manner in OVR and control females. Thus, the solute carrier family 8member 1 (SLC8A1) transcript that activates calcium influx was down-regulated in control females while transcript encoding the ATPase plasma membrane $\mathrm{Ca}^{2+}$ transporting protein (ATB2B), responsible for an 
efflux of calcium from the cardiomyocyte, was down-regulated in OVR females. In the latter, the gene encoding the myosin heavy chain 7B (MYH7B) contractile protein was also down-regulated by sepsis while tubulin alpha 8 (TUBA8) was decreased after sepsis in control and OVR females (Table 3 and supplemental Fig. 1).

\section{Effects of landiolol on cardiac function OVR females}

Both in control and OVR females, landiolol administration after sepsis did not affect physiological variables (Table 1).

Heart rate (HR) was lowered during landiolol administration in control and OVR females, although the difference did not reach a significant level. In control females, landiolol administered after sepsis decreased systolic blood pressure and mean blood pressure by $27 \%$ and $30 \%$ respectively $(p<0.01)$, as compared with sham. In contrast, landiolol administration after sepsis did not affect blood pressure in OVR females (Table 1). 
Table 3

Gene expression variation after sepsis

\begin{tabular}{|c|c|c|c|c|c|c|}
\hline \multirow[t]{2}{*}{ Biological process } & \multirow[t]{2}{*}{ Gene } & \multirow[t]{2}{*}{ Role } & \multicolumn{2}{|c|}{$\begin{array}{l}\text { Effect of } \\
\text { sepsis }\end{array}$} & \multicolumn{2}{|c|}{ Effect of landiolol } \\
\hline & & & Control & OVR & Control & OVR \\
\hline \multirow[t]{4}{*}{ Contraction } & TUBA-8 & \multirow{2}{*}{$\begin{array}{l}\text { Sarcomeres and } \\
\text { myosin organization }\end{array}$} & $\searrow$ & $\searrow$ & $=$ & Normalization \\
\hline & MyH7B & & $=$ & $\searrow$ & $=$ & $=$ \\
\hline & Slc8a1 & $\begin{array}{l}\text { Activation of } \\
\text { intracellular } \mathrm{Ca} 2+ \\
\text { entry }\end{array}$ & $\searrow$ & $=$ & $=$ & $=$ \\
\hline & ATP2B & $\begin{array}{l}\mathrm{Ca} 2+\text { plasma } \\
\text { membrane ATPase }\end{array}$ & $=$ & $\searrow$ & $=$ & Normalization \\
\hline \multirow[t]{7}{*}{ Inflammation } & JAK2 & \multirow{2}{*}{$\begin{array}{l}\text { Cell cycle and } \\
\text { survival }\end{array}$} & $\nearrow$ & $\nearrow$ & $=$ & $=$ \\
\hline & STAT3 & & $\nearrow$ & $\nearrow$ & $=$ & $=$ \\
\hline & IL-1b & \multirow[t]{4}{*}{ Pro-inflammatory } & $\nearrow$ & $=$ & $=$ & $\nearrow$ \\
\hline & IL-6 & & $\nearrow$ & $\nearrow$ & $=$ & $=$ \\
\hline & IL-18 & & $\nearrow$ & $\nearrow$ & $=$ & $=$ \\
\hline & TNF- $a$ & & $\nearrow$ & $=$ & $=$ & $=$ \\
\hline & IL-10 & Anti-inflammatory & $\nearrow$ & $\nearrow$ & $=$ & $=$ \\
\hline \multirow{3}{*}{$\begin{array}{l}\text { Adrenergic } \\
\text { signalling } \\
\text { pathway }\end{array}$} & $a-A R$ & Adrenergic receptor & $=$ & $\searrow$ & $=$ & $=$ \\
\hline & PLCb4 & $\begin{array}{l}\text { a-AR signalling } \\
\text { pathway }\end{array}$ & $=$ & $\searrow$ & $=$ & $=$ \\
\hline & GRK5 & $\begin{array}{l}\text { B-AR signalling } \\
\text { pathway (inhibition) }\end{array}$ & $=$ & $\nearrow$ & $\nearrow$ & $=$ \\
\hline \multirow[t]{3}{*}{ Apoptosis } & Akap6 & Anti-apoptotic & $\searrow$ & $\searrow$ & $=$ & $=$ \\
\hline & Mapk14 & Pro-apoptotic & $=$ & $\nearrow$ & $=$ & $=$ \\
\hline & CREM & & $\nearrow$ & $\nearrow$ & $=$ & $\searrow$ \\
\hline
\end{tabular}

In control females, after sepsis, landiolol decreased the cardiac global performances: $\mathrm{Cl}$ and SVi were decreased by $44 \%(p<0.0001)$ and $37 \%(p<0.01)$ respectively. Conversely, in OVR females, after sepsis, 
landiolol improved the impaired diastolic function and the cardiac global performances as EDVi was increased by $33 \%(p<0.01)$ and SVi by $51 \%(p<0.05)$ (Fig. 2). Landiolol did not affect LVEF and LVM in control and OVR females.

In control females, after sepsis, landiolol did not change EB lung tissue concentration. No differences of EB lung tissue concentration were found between OVR-sepsis females and OVR-sepsis plus landiolol females. There were no differences in lactate and procalcitonin plasma concentration between OVRsepsis females and OVR-sepsis plus landiolol females (Table 2).

Regarding transcripts regulation, landiolol increased the expression of the gene encoding GRK5 in control females. Conversely, in OVR females, landiolol restored the expression level of genes encoding TUBA8, ATP2B and CREM and up-regulated the transcript of IL-1b (Table 3 and supplemental Fig. 1).

\section{Discussion}

There is increasing evidence in the literature that gender, and particularly female hormones, affects the response to sepsis $(2,4,14)$. However, the mechanisms of this phenomenon remained to be demonstrated. To our knowledge, we provide the first study comparing cardiac performances in OVR and control female septic rats. A major point of our approach is the assessment of cardiac function using MRI, thereby providing an in vivo evaluation of cardiac function that includes heart-vessels interactions. Our results highlight disparities between control and OVR female rats. No impairment of cardiac performances after sepsis was observed in control females whereas in OVR females, sepsis decreased $\mathrm{SVi}$ and $\mathrm{Cl}$ related to an EDVi diminution.

Different mechanisms may explain this effect. The alteration in cardiac performance (decrease in SVi and $\mathrm{Cl}$ ) in septic OVR females was associated with a decrease in EDVi without effect on LVEF, DBP and MBP. This suggests a left ventricular diastolic dysfunction with a defect of filling during the diastole, while the venous return and the myocardial contractility were preserved. In our previous study (8), we showed that this effect was obtained in males, at variance with females.

Other experimental models have found improved survival in female mice after CLP compared to males $(10,14)$. This is in accordance with our present data in control females: in OVR septic females, the hemodynamic profile seemed to be close to that of septic males.

This suggests a protective effect of female hormones in sepsis, especially at the cardiovascular level. Female hormones have a protective effect on cardiac functions and cardiovascular response during major inflammation (4). Experimental administration of 17- $\beta$-œstradiol improved functional recovery after ischemia-reperfusion in rats (9). In an endotoxin-induced sepsis model, administration of 17- $\beta$ œstradiol mitigated septic cardiac dysfunction (15). Different mechanisms could explain the protective effect of female hormones in sepsis; an immunomodulatory effect of oestrogens has been reported in various models (16). 
Short acting $\beta$-blocker treatment may be a promising therapeutic approach in sepsis. Its efficacy has been shown in male rats septic models $(8,17)$. Our study confirms these findings in OVR females, since landiolol administration during sepsis improved SVi and $\mathrm{Cl}$ with an increase in EDVi. The present report suggests that the lack of effect of landiolol in females was mediated by female hormones. Thus, landiolol improved cardiac performance in conditions suggesting a reduced exposure to female hormones during sepsis.

In the second part of our study, we looked for the underlying mechanism of changes in hemodynamic profiles. We previously identified, in a transcriptomic study, major differences in sepsis-induced deregulation of gene expression in male and female rats and confirmed the benefit of landiolol intake on cardiac function in male (13). Our current results highlight a similar gene expression profile in OVR females to that found in males. Thus, genes involved in cardiac contraction, adrenergic signalling pathway and apoptosis were more deregulated in OVR females and partially restored with landiolol administration. No benefit of landiolol was found in control females. These results are in line with findings on the human cardiopathy during sepsis (18). In septic rat, dysregulation of genes involved in aadrenergic, $\beta$-adrenergic and calcium cycling pathway was associated with reduced survival (19). These transcriptomic regulations reduce the L-type calcium current (20) and increase the cytosolic calcium that lead to failure of diastolic relaxation, and decrease the calcium concentration in the sarcoplasmic reticulum, which affect systolic contraction as previously described in septic cardiomyopathy (21). Our MRI findings on cardiac performances and data on transcripts regulation are consistent with these studies.

In contrast to previous studies $(8,22)$, we did not show any significant decrease in HR during treatment with landiolol, regardless of hormonal status. This lack of difference may be explained by a relatively low number of analysed rats, which probably was a drawback for statistical correlations. Another possible explanation could be a sub-optimal dosage of landiolol. This, however, seems unlikely since we used the same dosage as that previously used to obtain a decrease in HR (8).

During sepsis, there are structural and functional changes in the endothelium responsible for endothelial dysfunction and microcirculation disorders $(23,24)$, resulting in higher permeability and oedema. Estradiol administration in male rats and in OVR females has been shown to improve intestinal microcirculation during sepsis (25). However, we found no significant differences in EB lung tissue concentration between the various groups, although there was a trend toward an increased permeability in OVR females. Further investigations are needed to define the effects of female hormones on pulmonary endothelium and microcirculation during sepsis.

Our study has several limitations. Our experimental model of sepsis, CLP, is considered as the reference method (26), but the main drawback of this method is its lack of reproducibility $(27,28)$. We attempted to reproduce the experimental conditions obtained in our previous study. However, we reduced the vascular filling performed during the 18 hours after CLP, to better mimic the initial phase of human septic shock. This resulted in an increased mortality in our septic animals. Nevertheless, we found deleterious 
consequences and more impaired cardiac performance in the rats assessed in the group with the highest mortality (sepsis plus landiolol females). Another limitation was that our study did not assess the baseline response to landiolol. Landiolol is hydrolysed to an inactivate metabolite by esterases, which activities are higher in female rats than in male rats (29). Whether this activity can be affected by OVR is unknown. Response to general anesthesia may also be sex-mediated (30), and therefore affected by OVR. Finally, the plasma concentrations of female sex hormones are likely to vary depending on oestrus cycle in females, and this cycle was not considered during sepsis.

\section{Conclusions}

Our model confirms that cardiac function was more impaired in septic OVR females, as compared with control females, suggesting a protective effect of female hormones on septic cardiac dysfunction. Landiolol, while it produced deleterious effects in control females, prevented cardiac dysfunction in OVR females due to an improvement in diastolic function, thereby mimicking its known effect in males. Differences in cardiac performances were related to transcriptomic changes in the myocardium in contraction, calcium cycling, adrenergic signalling, and apoptosis pathways, partially reversed in OVR females by landiolol administration. Interactions between sex hormones and $\beta$-blocker deserve further investigations on larger series to better understand the cellular mechanisms leading to a protective effect in sepsis.

\section{Declarations}

Acknowledgements: we are grateful to Magali Iche-Torres for technical support.

Fundings: This work was supported by France Life Imaging (grant ANR-11-INBS-0006).

\section{Author Contributions:}

Conceived the study: A.X, C.M, N.L, M.B and M.L. Performed surgeries: A.X. Performed tests: A.X, F.G, T.T, F.K and N.F. Performed analysis of results: A.X, F.G, F.K and N.L. Wrote manuscript: A.X, N.L, M.B and M.L. Revised manuscript and agreed with submission: All authors

\section{Additional Information:}

Competing interest: The authors declare that they have no competing interests

Number of words: Abstract, 266 words ; Text, 2913 words

\section{References}

1. Kisat M, Villegas CV, Onguti S, Zafar SN, Latif A, Efron DT, Haut ER, Schneider EB, Lipsett PA, Zafar H, Haider AH: Predictors of sepsis in moderately severely injured patients: an analysis of the National Trauma Data Bank. Surg Infect 14(1):62-68, 2013. 
2. Mahmood K, Eldeirawi K, Wahidi MM: Association of gender with outcomes in critically ill patients. Crit Care Lond Eng/16(3):R92, 2012.

3. Reade MC, Yende S, D'Angelo G, Kong L, Kellum JA, Barnato AE, Milbrandt EB, Dooley C, Mayr FB, Weissfeld L, Angus DC, Genetic and Inflammatory Markers of Sepsis Investigators: Differences in immune response may explain lower survival among older men with pneumonia. Crit Care Med 37(5):1655-1662, 2009.

4. Angele MK, Pratschke S, Hubbard WJ, Chaudry IH: Gender differences in sepsis: cardiovascular and immunological aspects. Virulence 5(1):12-19, 2014.

5. Offner PJ, Moore EE, Biffl WL: Male gender is a risk factor for major infections after surgery. Arch Surg Chic III 1960 134(9):935-938; discussion 938-940, 1999.

6. Gannon CJ, Pasquale M, Tracy JK, McCarter RJ, Napolitano LM: Male gender is associated with increased risk for postinjury pneumonia. Shock Augusta Ga 21(5):410-414, 2004.

7. Chen J, Chiazza F, Collino M, Patel NSA, Coldewey SM, Thiemermann C: Gender dimorphism of the cardiac dysfunction in murine sepsis: signalling mechanisms and age-dependency. PloS One 9(6):e100631, 2014.

8. Mathieu C, Desrois M, Kober F, Lalevée N, Lan C, Fourny N, Iché-Torres M, Tran TT, Lê LT, Singer M, Mège J-L, Bernard M, Leone M: Sex-Mediated Response to the Beta-Blocker Landiolol in Sepsis: An Experimental, Randomized Study. Crit Care Med 46(7):e684-e691, 2018.

9. Wang M, Tsai BM, Reiger KM, Brown JW, Meldrum DR: 17-beta-Estradiol decreases p38 MAPKmediated myocardial inflammation and dysfunction following acute ischemia. $J$ Mol Cell Cardiol 40(2):205-212, 2006.

10. Diodato MD, Knöferl MW, Schwacha MG, Bland KI, Chaudry IH: Gender differences in the inflammatory response and survival following haemorrhage and subsequent sepsis. Cytokine 14(3):162-169, 2001.

11. Kober F, Iltis I, Cozzone PJ, Bernard M: Cine-MRI assessment of cardiac function in mice anesthetized with ketamine/xylazine and isoflurane. Magn Reson Mater Phys Biol Med 17(3-6):157-161, 2004.

12. Wang H-L, Lai TW: Optimization of Evans blue quantitation in limited rat tissue samples. Sci Rep 4:6588, 2014.

13. Tran TT, Mathieu C, Torres M, Loriod B, Lê LT, Nguyen C, Bernard M, Leone M, Lalevée N: Effect of landiolol on sex-related transcriptomic changes in the myocardium during sepsis. Intensive Care Med Exp 7, 2019.

14. Zellweger R, Wichmann MW, Ayala A, Stein S, DeMaso CM, Chaudry IH: Females in proestrus state maintain splenic immune functions and tolerate sepsis better than males. Crit Care Med 25(1):106110, 1997.

15. Zhu H, Shan L, Peng T: Rac1 mediates sex difference in cardiac tumor necrosis factor-alpha expression via NADPH oxidase-ERK1/2/p38 MAPK pathway in endotoxemia. J Mol Cell Cardiol 47(2):264-274, 2009. 
16. Cristofaro PA, Opal SM, Palardy JE, Parejo NA, Jhung J, Keith JC, Harris HA: WAY-202196, a selective estrogen receptor-beta agonist, protects against death in experimental septic shock. Crit Care Med 34(8):2188-2193, 2006.

17. Suzuki T, Morisaki H, Serita R, Yamamoto M, Kotake Y, Ishizaka A, Takeda J: Infusion of the betaadrenergic blocker esmolol attenuates myocardial dysfunction in septic rats. Crit Care Med 33(10):2294-2301, 2005.

18. Matkovich SJ, Al Khiami B, Efımov IR, Evans S, Vader J, Jain A, Brownstein BH, Hotchkiss RS, Mann DL: Widespread Down-Regulation of Cardiac Mitochondrial and Sarcomeric Genes in Patients With Sepsis. Crit Care Med 45(3):407-414, 2017.

19. Rudiger A, Dyson A, Felsmann K, Carré JE, Taylor V, Hughes S, Clatworthy I, Protti A, Pellerin D, Lemm J, Claus RA, Bauer M, Singer M: Early functional and transcriptomic changes in the myocardium predict outcome in a long-term rat model of sepsis. Clin Sci 124(6):391-401, 2013.

20. Stengl M, Bartak F, Sykora R, Chvojka J, Benes J, Krouzecky A, Novak I, Sviglerova J, Kuncova J, Matejovic M: Reduced L-type calcium current in ventricular myocytes from pigs with hyperdynamic septic shock. Crit Care Med 38(2):579-587, 2010.

21. Duncan DJ, Yang Z, Hopkins PM, Steele DS, Harrison SM: TNF-alpha and IL-1beta increase Ca2+ leak from the sarcoplasmic reticulum and susceptibility to arrhythmia in rat ventricular myocytes. Cell Calcium 47(4):378-386, 2010.

22. Hagiwara S, Iwasaka H, Maeda H, Noguchi T: Landiolol, an ultrashort-acting beta1-adrenoceptor antagonist, has protective effects in an LPS-induced systemic inflammation model. Shock Augusta Ga 31(5):515-520, 2009.

23. Opal SM, van der Poll T: Endothelial barrier dysfunction in septic shock. J Intern Med 277(3):277293, 2015.

24. Russell JA, Rush B, Boyd J: Pathophysiology of Septic Shock. Crit Care Clin 34(1):43-61, 2018.

25. Sharawy N, Pavlovic D, Wendt M, Cerny V, Lehmann C: Evaluation of the effects of gender and estradiol treatment on the intestinal microcirculation during experimental sepsis. Microvasc Res 82(3):397-403, 2011.

26. Buras JA, Holzmann B, Sitkovsky M: Animal models of sepsis: setting the stage. Nat Rev Drug Discov 4(10):854-865, 2005.

27. Otero-Antón E, González-Quintela A, López-Soto A, López-Ben S, Llovo J, Pérez LF: Cecal ligation and puncture as a model of sepsis in the rat: influence of the puncture size on mortality, bacteremia, endotoxemia and tumor necrosis factor alpha levels. Eur Surg Res Eur Chir Forsch Rech Chir Eur 33(2):77-79, 2001.

28. Singleton KD, Wischmeyer PE: Distance of cecum ligated influences mortality, tumor necrosis factoralpha and interleukin-6 expression following cecal ligation and puncture in the rat. Eur Surg Res Eur Chir Forsch Rech Chir Eur 35(6):486-491, 2003.

29. Illsley NP, Lamartiniere CA: Endocrine regulation of rat serum cholinesterase activity. Endocrinology 108(5):1737-1743, 1981. 
30. Zambricki EA, Dalecy LG: Rat sex differences in anesthesia. Comp Med 54(1):49-53, 2004.

\section{Figures}

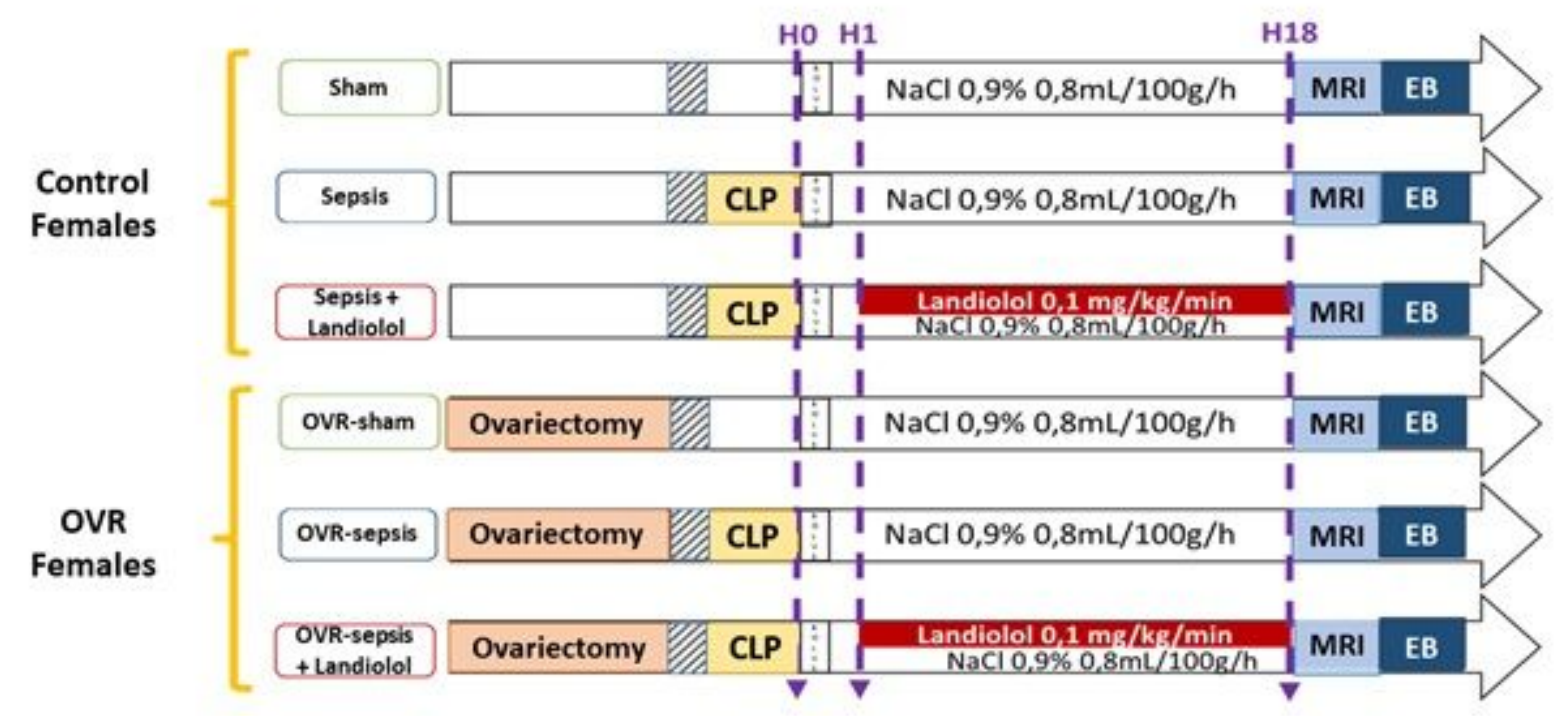

\section{Figure 1}

Experimental protocol. OVR: Bilateral ovariectomy CLP: Caecum ligation and punction. Bolus: $\mathrm{NaCl} 0,9 \%$ $1 \mathrm{~mL} / 100 \mathrm{~g} / \mathrm{h}$ in 30 minutes. MRI: Magnetic Resonance Imaging. EB: Injection of $80 \mathrm{mg} / \mathrm{kg}$ of Evans Blue 

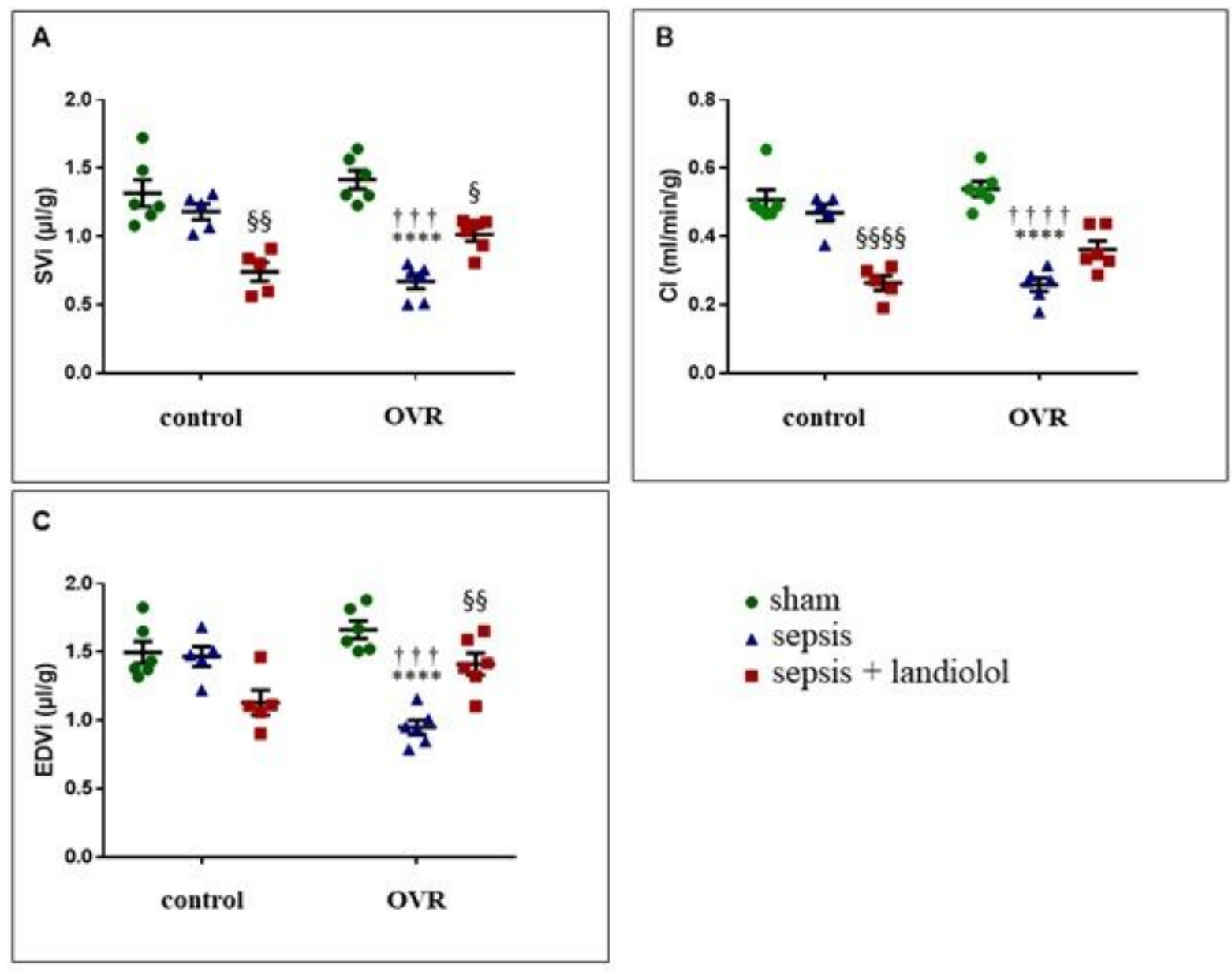
- sham
A sepsis
- sepsis + landiolol

Figure 2

Left ventricular cardiac parameters assessed by MRI of sham $(n=6)$, sepsis $(n=5)$, sepsis plus landiolol $(n=5)$, OVR-sham $(n=6)$, OVR-sepsis $(n=6)$ and OVR-sepsis plus landiolol $(n=6)$. A: Indexed stroke volume (SVi). B: Cardiac index (Cl). C: Indexed end-diastolic volume (EDVi). Data are expressed as means \pm SEM ${ }^{\star * \star *} p<0.0001$ vs sham and vs OVR-sham, respectively $\S p<0.05 ; \S \S p<0.01 ; \S \S \S \S p<0.0001$ vs sepsis and OVR-sepsis, respectively ††† $p<0.001 ; \uparrow+\uparrow † ~ p<0.0001$ vs control of corresponding group

\section{Supplementary Files}

This is a list of supplementary files associated with this preprint. Click to download.

- Supplementaldata.pdf 